\title{
Low Carbonation: an Effective Way for Sustainable Development of Residential Construction in China
}

\author{
Fen Li \\ School of Literature, Law and Economics \\ Wuhan Science and Technology University \\ Wuhan, China
}

\begin{abstract}
Energy conservation and carbon emissions reduction is an economic, social and political issue confronting countries around the world. Recent investigations have demonstrated enormous potential in energy consumption reduction in China's residential construction. Drawing on the statistic data and related documents, this paper analyzes the existing typical problems in residential construction development in China, i.e. large-scaled distribution, serious backwardness of energy conservation and relatively high energy consumption; then explores the underlying causes of the backward development in low-carbon and energy-saving residential construction, i.e. imperfect housing design, weak government regulation and limited public participation. Finally it concludes that to better solve those problems and develop a model of low-carbon residential construction, the government should actively cultivate awareness of low carbonation; enterprises ought to make innovation on lowcarbon technologies and design concepts; the public are to positively participate in the development of low carbonation.
\end{abstract}

Keywords-low carbonation; residential construction; sustainable development

\section{INTRODUCTION}

With the rapid development of economy and the increasing improvement of people's livelihood, the main consumption structures are gradually upgraded from clothing and food focused to housing and transportation focused. This upgrade will certainly confront the gradually high requirement for enhanced living conditions, such as housing floorage, interior environment, building location and residential supporting facilities, which engenders the rising energy consumption during the fulfillment of residential building function and will become the major source for energy consumption and carbon emissions increase in future. According to statistics, carbon emission in housing construction has accounted for $28 \%$ of total carbon emission (residential area accounts for more than $80 \%$ of the total construction), and is currently revealing a trend of expansion.

Against this backdrop, enhancing the development of low carbon and energy-saving housing will not only help solve the "bottleneck" problem of social, economic and ecological development in our country, but make great contributes to relieving global environment pressure. However, in the process of dealing with residential housing and transportation issues, the involved carbon emissions are difficult to reduce directly because they are often rigid. According to international experience, scientific technology, planning and management, and active public participation are indispensable in the process of cubing this rigid carbon emission in residential buildings. So adopting which kind of residential mode plays a crucial role in resolving issues like energy conservation, the construction of a low-carbon society and the resolution of climate deterioration.

\section{PROBLEMS OF RESIDENTIAL CONSTRUCTION DEVELOPMENT IN CHINA}

Under the context of an immense population and high economic growth, especially in late 2016 when the urbanization rate reaches up to $57.35 \%$, urbanization enjoys a highly expansion speed. In order to meet housing needs, Chinese residential construction is bound to achieve correspondingly high growth with following characteristics:

\section{A. Large-scale Development and Irrational Layout of Residential Construction}

Because of a large population, coupled with the rising level of income and living standards brought by rapid economic development, China's residential construction develops rapidly along with a large scale. According to National Bureau of Statistics, the total national area of residential construction was 54.1 billion sq $\mathrm{m}$ in 2015 , including that the total residential construction area in the rural areas was 26.5 billion sq $m$ with a population of 603.46 million and the per capita living space for rural residents reaching $43.9 \mathrm{sq} \mathrm{m}$; in the urban of the same year, the total residential construction area is 27.6 billion sq $\mathrm{m}$ with a population of 771.16 million and the per capita living space for urban dwellers reaching $35.8 \mathrm{sq} \mathrm{m}$; besides, a speed of more than 3.0 billion sq $\mathrm{m}$ of residential construction built in each year; while in 2016, the per capita living space for rural residents is $45.8 \mathrm{sq} \mathrm{m}$ but36.6sq $\mathrm{m}$ in city.

However, the distribution of residential construction in China is relatively scattered. In the countryside, traditional farming is primarily applied in agricultural production. For the convenience of cultivation, the rural people dwell in a scattered way with about 200 people in every natural village on the average, which determines the distribution pattern of residential buildings in rural areas. In the cities, in the wake of rapid economic development and the accelerated urbanization process, urban area sprawls rapidly. But 
because urban construction lacks systematic programming and management, the excessive pursuit of personality and comfort further results in the disperse and unscientific layout in urban residential construction. In general, there exist problems of large-scaled and irrational layout of residential construction in China.

\section{B. The Severe Backwardness of Low-carbon and Energy- saving Residential Construction}

Compared with developed countries, energy conservation work in China starts rather late. China's first Design Standards for Energy Efficiency of Residential Buildings (heating and residential parts) promulgated and implemented in 1986, which stipulated $30 \%$ energy conservation rate. The rate in the second standard of building energy conservation was required to be $50 \%$ in 1995 . In 2001and in 2003, China successively promulgated Design Standard for Energy Efficiency of Residential Buildings in Hot Summer and Cold Winter Zone and clearly defined the energy saving rate was $50 \%$. In addition, Law of the People's Republic of China on Conserving Energy in 1998 provides important guidance to the energy conservation in residential construction. Despite certain progress in design, operation, acceptance of the new energy-saving buildings in response to the regulations of building energy conservation, there is still a large gap compared with developed countries. And according to "State Council on further intensifying efforts to ensure the realization of emission reduction targets in 'National Eleventh-Five-Year Plan"'(promulgated by Order No. 12 of the President of the People's Republic in 2010), energysaving renovation of existing residential buildings is striving to reach more than $5 \%$, that is more than 2 billion square meters. But energy-saving construction still shares a small proportion in the total existing building area. Therefore, lowcarbon and energy-saving residential construction seriously lag behind, which is an arduous task of energy conservation in residential construction.

\section{The High Energy Consumption in Residential Construction Development}

The large-scaled and irrational-layout pattern of residential construction in China has inevitably led to huge energy consumption in residential buildings and their facilities. Along with the rapid development of residential building design and operation, there will be a corresponding increase in energy consumption. Especially global greenhouse effect causes the rapid increase in energy consumption in heating system and air-conditioners.

According to statistics, building energy-consumption in China covers from $10 \%$ of the total energy consumption in the 1970 s to $28 \%$ today, similar to $2-3$ times that in developed countries with similar climatic conditions in energy heating; steel consumption in residential construction makes up approximately $25 \%$ of the total steel consumption in China, while cement consumption accounts for $70 \%$ and wood consumption $40 \%$, and water consumption $32 \%$; all those energy consumption in building is 2-3 times of that in developed countries; and external walls, external windows and roofs of existing buildings in energy consumption are about 3-4 times higher than that in developed countries with similar climatic conditions.

Moreover, on the grounds of inadequate construction fund and backwardness in building concepts as well as technologies, the life expectancy of Chinese housing is lower than that of developed nations: generally less than 20 years in rural areas; less than 50 years in urban areas because of the renovation of the old city, changes in urban planning and backwardness in building function. The energy-saving residential housing occupies a small proportion (less than $5 \%$ ). Especially, in the process of urban residential construction there exist problems of over-sized housing units and surplus housing function. In such circumstances, our residential construction and use will inevitably have high energy consumption and grave waste, exceeding the energysupporting capacity and its growth speed of our country.

III. FACTORS RESTRICTING THE DEVELOPMENT OF LOWCARBON AND ENERGY-SAVING RESIDENTIAL CONSTRUCTION IN CHINA

Our residential construction has all along been plagued with serious resource waste, deteriorated ecological environment, and increased energy consumption and carbon emissions. Against the energy crisis and global warming background, the development of low-carbon and energysaving residential construction in China seriously lags behind, causing problems like heavy energy consumption and carbon emissions, greatly threatening the sustainable development of the whole society, economy and ecology. The main reasons will be elaborated as follows:

\section{A. Irrational Architectural Design Concepts in Low-carbon and Energy-saving Residential Construction}

Energy conservation of buildings is actually a complicated system engineering influenced by various factors. These factors not only include building structure, but also external and environmental conditions like meteorology and geography, supporting facilities, administrative management, and operation mode. However, from current design standards for energy conservation in residential buildings, people focus merely on energy conservation at the design stage, namely under weather conditions taking heating, ventilation, and air conditioners into account but ignoring the other influencing factors. In the upgrading process of consumption structure, people's demands towards living conditions improve continuously.

Especially the emphasis on the customized design of residential construction goes together with such phenomenon: the pursuit of spacious and well-lit unit structure leads to high energy consumption; the seeking of close-to-nature living conditions leads to excessive scattered residential construction; the ignorance of the way people use the house in the operation of energy conservation makes energy-saving residential buildings ineffective; the inadequate understanding on energy-saving residential buildings and the ignorance of properly governmental guidance and popularization result in resistance to the energy-saving residential buildings, which causes the serious backwardness of energy-saving residential construction. Therefore, under 
the present situation there exists irrational architectural design in low-carbon and energy-saving residential construction in our country.

\section{B. Insufficient Regulation Efforts in Low-carbon and Energy- saving Residential Construction}

Energy-saving system engineering of residential construction not only involves the interests of multiple participants but also public administration problems like the consumption of resources and energy, energy conservation and carbon emissions reduction, ecological environmental protection. The government has the responsibility to carry out macroeconomic regulations and control on energy-saving residential construction which has 20 years' history in China and still has failed to be largely popularized. The underlying cause lies in the imperfect institutional system of energysaving residential construction: (1) China lacks the laws and regulations on energy conservation. As a macroscopic regulation, Law of the People's Republic of China on Conserving Energy lacks the clear regulations on energy-saving buildings, involves little about management and legal responsibilities of building energy conservation, and has barely enough constraining power on energy-saving residential construction; (2) Design Standards for Energy Efficiency of Residential Buildings only refers to the design stage, including the consumption of heating, ventilation, and air conditioners, but without systematic management and supervision especially the explicit demand on administrative management and responsibilities; (3) the present related system of energy-saving residential construction, like energy supply and metering charges, either is deficient or hinders the development of energy-saving residential construction. Thus, due to the insufficient regulation efforts in low-carbon and energy-saving residential construction, the operation does not follow the standards or the calculated results of design, which leads to the construction below the standard requirements and serious backwardness of energy-saving residential construction.

\section{Inadequate Awareness of Public Participation in Energy-saving Residential Construction}

The inadequate awareness of public participation is another significant factor of the serious backwardness in energy-saving residential construction. Now in China, the general public has an inadequate understanding on the significance of energy- saving residential construction and a weak consciousness on the resources and energy crisis. At the same time the decision-making level has failed to support technique innovation adequately on residential energy conservation, and has publicized the concept of building energy conservation insufficiently which causes the scattered demonstration of energy-saving plots to fail to play its desired effect. All those phenomena lower public participation.

The underlying factors involve two aspects. The first is that government and relevant departments do not yet fully understand the residential energy conservation. Neither have they grasped the urgency of this development from the aspects of national resources and energy security, and ecological sustainable development; nor have they understood the significance from the change in growth mode and the adjustment of economic structure. Those deficiencies lead to the government's insufficient support on guidance, education and propaganda of low-carbon and energy-saving residential construction and inadequate public awareness of energy conservation. The other is that the public lack the comprehensive understanding of relevant knowledge and policies of energy-saving buildings, which leads to insufficient participation and stay-out-of- the-way attitude.

Low-carbon and energy-saving residential construction are also related with the factors like architectural technologies, architectural material, different climate features, economic development situation and resource supplies etc. But the author thinks that the weak consciousness from all social public is the basic problem in low-carbon and energysaving residential construction.

\section{PROPOSALS FOR IMPLEMENTATION OF LOW-CARBON AND ENERGY-SAVING RESIDENTIAL CONSTRUCTION}

China consumes the world's 7\% arable land, $7 \%$ freshwater, $4 \%$ oil, $2 \%$ natural gas, etc. to maintain the survival needs of $21 \%$ of the world's population. This is a tremendous project, especially under the problem of slow energy-saving residential construction and rising carbon emissions in the process of rapid residential construction. Combined with specific targets of energy conservation and emissions reduction, low-carbon development mode for residential construction is a main melody of housing construction in our country. Therefore, under the guidance of scientific concept of development, to lower carbon emissions in residential construction the following major measures should be taken to transform the sustainable development mode and establish a low-carbon development mode for residential construction so as to meet the demand of economy and environment.

\section{A. The Active Participation of the Government to Foster the Sense of Low Carbonation}

From a practical point of view, the new residential buildings have huge energy-saving potential. But market has failed to work occasionally and government intervention is needed in residential energy conservation. This requires that, on the one hand, the government should perfect the energysaving laws and regulations, and establish the incentive institution for residential construction from the national strategic level. To reply the requirements of the low-carbon emission and energy conservation in residential construction, the government should take existing issues in residential construction and develop objectives into account based on the existing residential development legal system; merge the low-carbon technology and ideas into law and regulations, technical specifications, decision-making during residential construction; build a sound long-term mechanisms and policy support systems for low-carbon residential construction. Meanwhile, the government should establish monitoring and evaluation mechanisms, and the perfect dynamic evaluation index for low-carbon emissions in energy-saving residential construction; refine the management practices and enforce responsibility system in 
implementing the residential construction in order to form the workable measures.

On the other hand, the government should plan and guide the development of low-carbon and energy-saving residential construction. Facing the social, economic and political issue of energy conservation and carbon emissions reduction, the government should firstly have clear principles, goals and guiding ideas for low-carbon and energy-saving residential construction; then provide technical support and create financing environment for low-carbon and energy-saving residential construction. Furthermore, the government has the responsibility to nurture awareness of energy-saving residential construction, cultivate the concepts of low-carbon consumption and low-carbon life among the public with the goal of increasing public participation in low-carbon society. In addition, the government should implement a series of policies such as financial subsidies, interest payments on loans, subsidies in the form of rewards, capital injection, seeds fund and other methods to promote and encourage the low-carbon residential construction.

\section{B. The Corporate Innovations in the Low-carbon Technology and Design Concepts}

At present, great energy-saving potential is shown in the facts that Chinese residential energy consumption accounts for $28 \%$ of the total energy consumption and that China's per unit area of heating energy consumption is 2-3 times higher of that in developed countries with similar climatic conditions. It is calculated that if residential energy consumption is reduced by a half, the total energy consumption will have a $10 \%$ cut.

Under these circumstances, in accordance with China's resources and energy supply, climate characteristics, housing thermal characteristics, enterprises should refer to the international and domestic scientific and technological achievements, and follow the principles of "local conditions", "full-life-cycle analysis", "weighing optimization" and "fine and specialization".

Then the enterprises should select and innovate application technologies; optimize the layout of residential flat and three-dimensional structure; design the rational residential buildings with outer protective structure, exterior windows and roof structure; control shape coefficient and heat transfer coefficient; reduce residential energy consumption coefficient; adopt decentralized and centralized residential layout; make full use of residential supporting facilities; reduce the distance of residents' daily transportation and energy loss level; make rational use of resources and clean energy; build circular economic system of energy use. Simultaneously, the enterprises should establish a low-carbon residential construction model, reduce ground and pavement hardening, and enhance function of "carbon credits" and "water credits" in the residential environment.

\section{Active Public Participation in the Low-carbon Development}

Low-carbon concept is the core of the sustainable development of society and economy. The public not only should change the consumption and dwelling concepts, including changing the previous lifestyle of high energy consumption and high pollution, establishing consciousness of low-carbon life and consumption; but also should actively participate in decision-making and implementation process of low-carbon and energy-saving residential construction to fulfill the scientific and democratic process.

Thus governments should popularize the knowledge of low-carbon and energy-saving residential buildings in the whole society; vigorously propagate the significance of lowcarbon and energy-saving residential construction for the nation, enterprises and personal development in order to raise public awareness of building energy conservation and foster the demands for low-carbon and energy-saving residential buildings. Meanwhile, governments should standardize the operation of low-carbon residential construction, strictly implement the regulations and standards of energy-saving residential construction, urge the enterprise to comply with professional ethics and realize the energy-saving standards and effect in completed residential buildings. Above all, increasing public awareness is the foundation to achieve the goal of building energy conservation. Only by enhancing the general public's awareness of energy conservation can customers have strong social demand towards low-carbon and energy-saving residential buildings, and can developers real care for them for the sake of profit.

In summary, low-carbon and energy-saving residential construction is a complicated systematic project, whose development needs governments' leadership. By means of policy guideline, scientific planning and concept education, governments should exert all strength to promote the enterprises' low-carbonation technology innovation and enhance energy-saving residential construction so as to make the public positively involve in this process, and realizing the goal that people have a green lifestyle and our country has a sustainable development in future.

\section{CONCLUSION}

Low-carbon and energy-saving residential construction is not only an inevitable choice in the shift from industrial civilization to ecological civilization, but the only way to insist on "man-oriented" and "ecology-oriented" and promote the sustainable development of society. Implementing the low-carbon concept, developing lowcarbon economy, constructing low-carbon buildings, and merging low carbonation concept into the energy-saving residential construction and people's lives can help to upgrade industry, increase the efficiency in energy utilization, control environmental degradation, ease ecological pressure, form the energy-saving and environment-friendly society, and promote harmonious development between man and nature. In the process of low-carbon and energy-saving residential construction, we must give full play to the role of government; make comprehensive planning with the lowcarbon concept based on comprehensive consideration of natural resources situation and social and economic development; establish the multilateral operation systems of government-led-market-adapted-public participated; pay 
particular attention to enterprise and its role; popularize and inculcate low-carbon concept to transform people's consumption concepts and encourage them to contribute to low-carbon development.

\section{REFERENCES}

[1] China Statistical Bureau:2016, http://www.stats.gov. cn/tjsj/sjjd/201701/t20170120_1456174.html.

[2] Qiu Baoxing. The Transformation Trends of Urban Development Model in China:Low Carbon Eco-city.Urban Studies, 2009; (8): 1-6.

[3] Liu Lingde. The State of Architectural Energy Saving, Energy Saving and Emission Reduction Planning and Design and Renewable Energy Utilization in China.Hydropower Station Design, 2009; (12): 107-112, 118.

[4] Sutherl, Ronald J. Market Barriers to Energy-efficient Investments. The Energy Journal, 1991; 12(3): 15-34.

[5] Li Guomin, Lu Ke. Reform and Path of Urban Land Low-carbon Use Patterns. China Population Resource and Environment, 2010; (12): 62-63. 